Die hemmende Wirkung der DOG auf die Äthanoloxydation durch Hefezellen muß unserer Meinung nach auf andere Ursachen zurückgeführt werden. Wir vermuten, daß entweder DOG oder ihr Phosphorylierungsprodukt, das DOG-6-Phosphat, direkt oder indirekt eine Atmungshemmung hervorruft. Die Versuche bekräftigten an einer anderen Zellart die von uns an Ascitestumorzellen gewonnenen Ergebnisse ${ }^{2}$, in denen ebenfalls unterschiedliche Wirkungen von Glucose und DOG auf den Stoffwechsel dieser Zellen gezeigt werden konnten.

Physiologisch-chemisches Institut der Medizinischen Akademie, Magdeburg

$$
\text { E. Hofmann, H. Mucke und I. Behne }
$$

Eingegangen am 30. Oktober 1961

*) Wir halten die Bezeichnung ,Crabtree-Effekt" für die durch DOG induzierte Atmungshemmung bei Hefe- und Ascitestumorzellen $\left.^{1}\right),{ }^{2}$ ) für unrichtig.

1) Kiesow, L.: Z. Naturforsch. 16b, 32 (1961). - 2) HoFManN, E., S. König u. I. Bekne: Naturwissenschaften 49, 40 (1962).

\section{Sedimentation Studies on DNA from Irradiated E. coli}

Not much work had been reported on the effect of ionizing radiation on DNA inside the cell ${ }^{1}$, , ${ }^{2}$ ). In an attempt to study the effect of radiation on DNA from irradiated $E$. coli sedi-

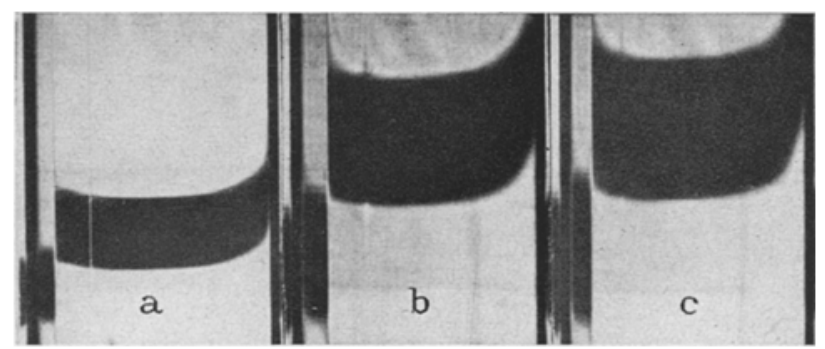

Fig. 1. Hypersharp schlieren patterns of E. coli DNA at speed of revolutions 39460 per min. $a$ Conc. $0.0255 \%$, bar angle $35^{\circ}$; cells unexposed. $b$ Conc. $0.0036 \%$, bar angle $19^{\circ}$; cells exposed to

27 kilorads. $c$ Conc. $0.0036 \%$ bar angle $17^{\circ}$; cells unexposed

mentation studies on DNA extracted from normal and irradiated cells were done.

The wet weight of the $E$. coli cells collected from 12 hours old slant cultures was about 1 to $2 \mathrm{~g}$. These cells were then either exposed to $70 \mathrm{kV}$. X-rays or kept as controls. Extrac tion of DNA from these cells was done by MARMUR's method ${ }^{3}$ ) immediately after the collection or after the radiation. White fibrous DNA finally collected was dried in air and dispersed in standard saline citrate buffer $(0.15 \mathrm{M} \mathrm{NaCl}+0.015 \mathrm{M} \mathrm{Na}$ citrate) by storing in cold for about 48 hours.

Concentrations of DNA solutions were determined from diphenylamine reaction. Collected DNA contained protein less than $1 \%$ and RNA less than $3 \%$. The schlieren optical patterns of $E$. coli DNA with Spinco ultracentrifuge, $12 \mathrm{~mm}$ cell thick ness, at a speed of revolutions 39460 per sec were hypersharp sedimenting peaks, even at the concentration as low as $0.0036 \mathrm{~g}$ per $100 \mathrm{ml}$ (Fig. 1). This observation was true for DNA from both control and radiated cells.
The reciprocal of the sedimentation coefficients of DNA from control and irradiated $E$. coli, with respect to water at $20^{\circ} \mathrm{C}$ has been plotted in Fig. 2 against the concentrations. The various exposure doses to the cells have been shown by distinctive symbols on the graph. The different sedimentation coefficients for the DNA from irradiated and control cells fall on the same curve, so that the sedimentation coefficient extrapolated to zero concentration $\left(S_{20, w}^{0}\right)$ is 31 Svedbergs for DNA from both control and irradiated cells. This value of $\mathrm{S}_{20, \mathrm{~m}}^{0}=31 \mathrm{~S}$.U. agrees very closely with the value obtained by HEARST and VINOGRAD ${ }^{4}$ ) for DNA from control $E$. coli, at a speed of revolutions 39460 per min.

The same value of $S^{0}$ for DNA from both control and irradiated cells indicated that there was no change in the

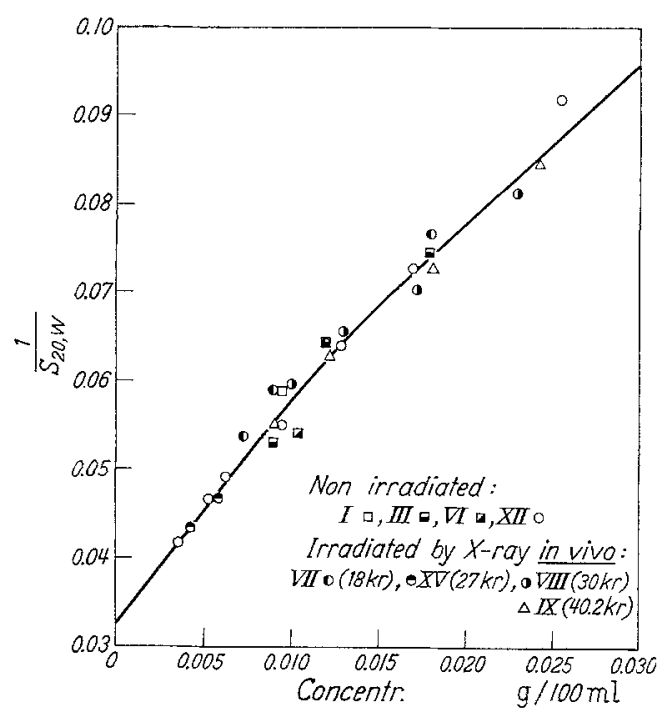

Fig. 2. Variation of $1 / S_{20, w}$ with DNA concentrations. E. coli DNA in $0.15 \mathrm{~N} \mathrm{NaCl}+0.015 \mathrm{M}$ Na-citrate. Absc.: concentration in $\mathrm{gm} / 100 \mathrm{ml}$; Ord.: $1 / S_{20, \mathrm{w}}^{0} \cdot S_{20, \mathrm{w}}^{0}$ for zero concn. $=31$ Svedberg units $=31 \cdot 10^{-13} \mathrm{sec}$

molecular weight of DNA due to radiation of the cells up to 40 kilorads.

The work was done under the financial sponsorship of the Council of Scientific and Industrial Research, India. Thanks are due to Mr. A. Bhattacharya vor helping in some of the ultracentrifugal experiments.

Biophysics Division, Saha Institute of Nuclear Physics, Calcutta-9, India

P. K. Ganguli, S.B. Bhattacharjee and N.N. Das Gupta

Eingegangen am 10. Februar 1962

1) Amos, N., and J.W. Rowen: Biochim. Biophys. Acta 22 203 (1956). - 2) ButLer, J.A.V., in: Nucleoproteins (Edt. R. Stoop). New York: Interscience Publishers 1959.-3) MARMur, J. J. Mol. Biol. 3, 208 (1961). - ${ }^{4}$ ) HeARST, J.E., and J. Vinograd: Arch. Biochem. Biophys. 92, 206 (1961).

\title{
Budhbesprechungen
}

Goethe: Die Schriften zur Naturwissenschaft. Hrsg, im Auftrage der Deutschen Akademie der Naturforscher (Leopoldina) von R. MAtThaE, W. Troll und K. L. WoLF. Bd. I/6: Zur Farbenlehre, Historischer Teil. Bearbeitet v. D. KuHN. Bd. II/6: Ergänzungen und Erläuterungen dazu. Bearb. v. D. KUHN und K. L. Wolf. Bd. I/7: Zur Farbenlehre. Anzeige und Übersicht, statt des supplementaren Teils und Erklärung der Tafeln. Weimar: H. Böhlaus Nachfg. 1957 bis 1959. Bd.I/6 XVII, 450 S. Gzl. DM 25,50. - II/6: XXX, 640 S. Gzl DM 33,75. I/7:V, 135 S. u. 24 zum Teil farbige Tafeln. Gzl. DM 27,50.

Wer sich einen Überblick über GoETHEs Farbenlehre verschaffen will, wird einen Wegweiser in dem schmalen Band I/7 finden. Der Inhaltsbericht Gosthes läßt in Kürze das Wesentliche der Komposition, der Zielsetzungen und Gedankenwege hervortreten. Die vorzüglich ausgestatteten Bildtafeln nebst Erläuterungen führen in die Problematik ein. - Die Buchbände der Leopoldina-Ausgabe folgen der Goetheschen Gliederung; sie enthalten in der I. Abteilung die Texte, und zwar in $1 / 4$ den didaktischen, in $\mathrm{I} / 5$ den polemischen, in $\mathrm{I} / 6$ den histori schen Teil zur Farbenlehre.

In der II. Abteilung bringen die Herausgeber zu jedem Band der I. Abteilung einen Band mit Materialien, Zeugnissen und Erläuterungen. Die beiden Bände 6 , die den historischen Teil betreffen, stehen hier zur Besprechung. - Der Textband "Materialien zur Geschichte der Farbenlehre", von GOETHE selbst verfa $\dot{B} t$ und angeordnet, fand eine sorgfältige Redaktion. Der entsprechende Band der II. Abteilung forderte eine umfangreiche Arbeit. Man gewinnt den Eindruck, daß er gewissenhaft und gründlich zusammengestellt und vorbildlich geordnet 